\title{
When Governments and International Organizations Shut Down: The Impact of COVID-19 on Refugees' and Host Community's Use of Educational Services in Cox's Bazar
}

\author{
Haakon Gjerløw ${ }^{1 *}$, Sabrina Karim ${ }^{2}$ and Gudrun Østby ${ }^{1}$ \\ ${ }^{1}$ Peace Research Institute Oslo, Oslo, Norway, ${ }^{2}$ Government Department, Cornell University, Ithaca, NY, United States
}

OPEN ACCESS

Edited by:

Kay Fuller,

University of Nottingham,

United Kingdom

Reviewed by:

Diotima Chattoraj,

National University of Singapore,

Singapore

Abu Reza Md. Towfiqul Islam,

Begum Rokeya University,

Bangladesh

Md Shariful Islam,

North South University, Bangladesh

Joanna McIntyre,

University of Nottingham, United Kingdom

*Correspondence: Haakon Gjerløw

haagje@prio.org

Specialty section: This article was submitted to Leadership in Education, a section of the journal

Frontiers in Education

Received: 16 April 2021 Accepted: 28 May 2021

Published: 16 June 2021

Citation:

Gjerløw H, Karim S and Østby G (2021) When Governments and International Organizations Shut Down: The Impact of COVID-19 on Refugees' and Host

Community's Use of Educational

Services in Cox's Bazar.

Front. Educ. 6:696176.

doi: 10.3389/feduc.2021.696176
At the global level, COVID-19 not only shut down many services that national governments provide to public, but it also severely limited the ability of international organizations to deliver services during humanitarian crisis. We suggest that the absence of governments and INGOs creates a vacuum for informal institutions to increase their reach. In this research note, we present novel phone survey data on education services in Cox's Bazar, Bangladesh with host communities and refugees. We show that the number of households without access to education decreased during lockdown, but that the impact was different for the refugee population and the host population. This is because the refugee community relied on their prior ties to informal education, whereas the host community did not have the same ties to multiple informal options. Overall, we show that informal institutions provide a substitute for governments and international organizations when they shut down.

Keywords: education, refugee, public service, international organization, Bangladesh

\section{INTRODUCTION}

International organizations such as United Nations High Commission for Refugees (UNHCR), International Organization for Migration (IOM), United Nations Children's Fund (UNICEF), and others regularly work with partners and donors to provide services to refugees around the world. The literature suggests that variations in service provision by international organizations and host governments sometimes cause conflict between the refugee and host communities (Alix-Garcia et al., 2018). Yet, the dual involvement of governments and INGOs in service provision allows states to host refugees, and helps states manage refugee influxes that host populations communities might find threatening. But, what happens when both the government and INGOs shut down?

At the global level, not only has the COVID-19 pandemic shut down governments all over the world, but it has also severely limited the ability of international organizations to deliver services during humanitarian crisis. ${ }^{1}$ We posit that refugees and the local population turn to the informal sector to receive the services they need, but that refugees will have more success in finding alternatives to service provision than the host population. This is because refugees tend to have

${ }^{1}$ See https://www.washingtonpost.com/politics/2020/05/18/5-ways-coronavirus-is-making-worlds-most-vulnerable-lot-morevulnerable/. 
links to multiple informal channels. As such any service deficit that existed between refugees and host population prior to the COVID-19 pandemic may actually disappear when formal service providers shut down.

Using the example of educational services, a sector for which both governments and INGOs are responsible in refugee camps and/or local host communities, we evaluate the effect of a sudden absence of formal educational services due to the COVID-19 pandemic in Cox's Bazar, Bangladesh. Using our phone-survey sample of 616 Rohingya refugee and host population households, we show that half of all households did not have access to any educational services during the lockdown. However, the host community turned to private tutors during the lockdown, and refugees relied on private tutors, religious educational services as well as community based education services. The evidence shows that while education for refugees and the host community declined drastically during COVID-19, the availability of informal service providers provided an important safety net for refugees in particular. This implies that the absence of the government and INGOs could lead to informal actors gaining a foothold in service provision and governance. However, our data also indicate that a majority of households do not use any educational services during the pandemic; an ill omen for the next generation.

\section{INTERNATIONAL ORGANIZATION GOVERNANCE}

In countries that host refugee populations, IO's are primarily responsible for their service provision. International humanitarian organizations ensure collaboration, coordination, and cooperation for saving the lives, reducing the suffering, and enhancing the welfare of the world's most vulnerable and neglected populations (Caplan 2005; Barnett 2013). They become sources of governing authority for refugees, stateless people, and other groups who live within the national territory of a particular country. Particularly when government state capacity is low and/or elite divisions high, international actors provide a governance substitute (Miller 2017). However, when governments host IOs that serve refugees, it sets up two governance structures within the same country that may at times be the source of grievances between the refugee and host population (Alix-Garcia et al., 2018).

Yet, despite host population resentment of IO service provision to refugees, many national governments are likely to be more effective in the provision of goods and services than international actors. Like national governments, international organizations must have capacity and cohesion to provide these services (Littoz-Monnet 2017; Campbell 2018; Lake 2018; Schneiker et al., 2018), but are likely to have less of these resources compared to national governments, for three reasons. First, national governments have multiple and diversified revenue generating streams-they can borrow, tax, and receive funds from international aid. International organizations rely solely on the funds from donor countries. These funds are often times restricted in what they can be used for, as multilateral aid is often conditional (Bayram and Graham 2015), and often depends on the political goals of donor countries (Nelson 1986; Whitaker 2008). This means that international organizations are more likely than national governments to have their hands tied with respect to funding service provision. Second, in most cases, national governments rely on legitimacy conferred onto them by their citizens via the provision of goods and services (Risse and Stollenwerk 2018), which means that national governments have an incentive to consistently provide goods and services to the public. International organizations only need the approval of those that they serve in order to be legitimate, and have less of an incentive to consistently provide goods and services to those under their jurisdiction. Finally, the multitude of international organizations, the international laws that govern them, and the absence of a international sovereign make cooperation and coordination more difficult at the global level. Competing interests and overlapping mandates among international organizations can reduce the quantity and quality of goods and service provision (Frey 2008; Gray 2018). The observable implication from these differences is that when comparing the same sector of service provision-education, for example-the provision of the service by the government to its citizens will be better than the service provision by IO's. Where international organizations operate and govern such refugee camps, then, refugees will experience a service deficit when compared to the host community.

\subsection{When International Organizations and National Governments Shut Down}

While it is very rare, there are certain events that cause the collapse of formal governance. Global pandemics or other disasters temporarily shut down the ability of governments and international organizations to continue to provide services. One consequence is that refugees become worse off while the host population continues to accumulate capital. The initial poor service provision (to refugees) predicts larger service deficits during a shutdown (between refugee and host communities), because the shutdown reinforces the structural inequalities that existed prior to the shutdown (Egede and Walker 2020).

However, we counter-intuitively suggest that shutdowns do not necessarily disproportionately reduce access to services for refugees relative to the host population because refugees may have more access to informal service providers. In many areas, sources of informal governance authorities provide public goods and service provision in competition with formal sources of authority (Risse and Stollenwerk 2018). Non-state actors, such as traditional leaders, religious leaders, or even insurgent, gang or criminal networks often provide goods and services to communities (Skarbek 2011; Arjona, Kasfir, and Mampilly 2015; Schmelzle and Stollenwerk 2018; Lessing and Willis 2019). They fill the governance voids where international organizations or state governments are unable to provide goods and services. Where the service gap is larger, such as in refugee camps, these informal authorities may have more power, influence, and capacity. As such, there are a higher number of options for service provision (Yassin et al., 2016). 
With more options, refugees develop skills to navigate the competing governance authorities, and develop creative strategies to improve their situation (Mahoudeau 2019). Where there is less of a service gap, such as in areas that governments controls, there are likely fewer service options for citizens, as the state provides most of the goods and services. As such, they may not develop multiple networks and ties to other, informal governing authorities. The observable implication here is that refugees are likely to have multiple options of service providers, whereas host communities are likely to have fewer options for service provision. Moreover, this means that when formal service provision shuts down, informal service providers fill the formal governance void, and because refugees have more informal options, their service deficit may be on par with the host community instead of larger. That is, refugee and host communities may experience similar levels of a decrease in service provision when international organizations and national governments shut down even though refugees have a larger deficit at the start. Additionally, those who have multiple links to informal sources of service provision will be more likely to receive services during the crisis, but the services provided will be from informal sources.

\section{GOVERNANCE IN REFUGEE AND HOST POPULATION CONTEXTS: A CASE STUDY OF THE EDUCATION SECTOR IN COX'S BAZAR, BANGLADESH}

One of the most basic services that all formal governance authorities provide is education (Cohen and Bloom, 2006). Indeed, the provision of basic education to children is nearly universally recognized service for governments to provide. It is also recognized by the global community under Sustainable Development Goal 4. Because educational services represent a service that both governments and IOs provide, it is an ideal sector to study when comparing the effects of formal governance shutdown. In 2020, the COVID-19 pandemic shut down educational services around the world. Prior to the COVID-19 pandemic, the proportion of children and youth out of primary and secondary school worldwide had declined from 26 per cent in 2000 to 19 per cent in 2010 and 17 per cent in $2018^{2}$.

Access to education for Bangladeshi children has drastically improved over the past several decades (ChowdhuryMushtaque and Choudhury, 1999; ChowdhuryMushtaque et al., 2003). In a country of over 18 million primary school students, Bangladesh has achieved near universal net primary enrollment, with approximately 98 percent of children of primary school age enrolling in school and the percentage of children completing primary school is close to 80 percent. $^{3}$

In Bangladesh, it is important to distinguish between formal (or mainstream) and non-formal education. In line with

\footnotetext{
${ }^{2}$ https://www.un.org/sustainabledevelopment/education/

${ }^{3}$ See https://www.worldbank.org/en/results/2016/10/07/ensuring-education-forall-bangladeshis
}

UNESCO's definition, we understand formal education as education that is institutionalized, intentional and planned through public organizations and recognized private bodies, and which constitute the formal education system of a country. Formal education programmes are hence recognized as such by the relevant national education or equivalent authorities. ${ }^{4}$ The former education institutions in Bangladesh cover government schools as well as private schools that use curriculum and textbooks prescribed by the National Curriculum and Textbook Board (NCTB). The language of instruction in these schools is Bangla, and like the public schools, government conducts national examinations for the students of private schools. Apart from the mainstream education system, there is also parallel educational system comprising religious institutions known as Madrasa for students who would want to study the Islamic religious subjects (Mousumi and Kusakabe 2020).

Bangladesh's Ministry of Primary and Mass Education (MoPME) is responsible for primary education (grades 1-5), and the Ministry of Education (MoE) oversees secondary and post-secondary education. In the early 1980s, the government undertook a scheme to modernize the madrasas education system whereby secular subjects such as English, Bengali, Science and Mathematics would be taught along with religion-related subjects and languages (Asadullah and Chaudhury 2010). These "Aliyah" madrasas are registered with a government board.

Educational services to Rohingya refugees is different than for Bangladeshi children. Rohingya refugee children are barred from enrolling in schools in local communities outside the camps or taking national school examinations. The Bangladeshi government forbids unregistered refugees from accessing the country's formal education institutions. Instead, major organizations like UNICEF, BRAC, and other large international NGOs are providing nonformal education programmes in so-called "learning centers" in the Rohingya refugee camps (Dupuy and Gjerløw, 2019). The purpose of the non-formal learning centers is to provide an alternative for learners not able to access formal education. Most non-formal learning centers teach basic language and mathematics, as well as drawing, singing and basic life skills. Here Bengali language is not allowed, and the medium of teaching is Burmese and Chittagonian language (Dupuy and Østby 2019).

In addition to the IO and NGO-run learning centers, Islamic religious schools (e.g. madrasas) operate within the camps, as do networks of private tutors and informal or ad-hoc schooling arrangements. These educational services operate more informally, and are therefore not subject to regulations from the Bangladeshi government. It is assumed that this market exists because of the low quality on the services provided by ios and NGOs, as households have greater demands for education that these services can satiate.

Since August 2017, more than 650,000 Rohingya people have fled violence and persecution in Rakhine State in Myanmar, bringing the total number of Rohingya refugees in Bangladesh to more than 900,000 (Ullah, Hossain, and Chattoraj 2020, p.

\footnotetext{
${ }^{4}$ See http://uis.unesco.org/en/glossary-term/formal-education
} 
795). More than half of the Rohingya population are children, and over 530,000 children aged 3 to 17 are in immediate need of education in emergency services, which are provided by ios (Cox's Baar Education Sector 2018).

\section{COVID-19 AND EDUCATION IN BANGLADESH}

COVID-19 is a highly contagious virus that causes respiratory illness and can be fatal unless treated. In countries were the spread of the virus spiraled our of control, such as Italy in the spring of 2020 or India in the spring of 2021, the demand for intensive care far exceeded the available capacity. This caused excess deaths also for other patient groups due to lack of treatment. Most countries have therefore drastically limited individual liberties and shut down several public services in order contain the spread of the virus (Hale et al., 2021). Such lockdown-measures have created huge costs for national economies and have led to the largest disruption of education in history, affecting nearly 1.6 billion learners in over 190 countries (Fund 2020; Siam et al., 2021; Ullah, Nawaz, and Chattoraj 2021).

Bangladesh confirmed the first coronavirus case on March 8, 2020 , which led to the declaration of a "general leave" from March 26, 2020 to May 30, 2020. During this time, schools shut down across the country (Chowdhury, 2020). The Refugee Relief and Repatriation Commissioner (RRRC) (based in Cox's Bazar) defined education as a non-essential activity in the pandemic response, and all NGO-run learning centers in the camps closed (Pillai and Zireva 2020). Within the Cox's Bazar district, the government forbade anyone from leaving or entering the district and blocked access to the camps for most humanitarian aid workers. An estimated 80 percent of aid workers were stopped from entering and leaving the camps (Spoerri, Ullah, and Nwangwu 2020). At the time of writing in May 2021, education services have not yet reopened, and it possible that a new peak will hit Bangladesh later in 2021 (Arifuzzaman et al., 2021).

\section{RESEARCH DESIGN}

In order to evaluate the effect of a sudden absence of formal educational services due to the COVID-19 pandemic isn Cox's Bazar, Bangladesh, we partnered with IPA Bangladesh to conduct a phone-survey of 719 households, of which 366 were from the Rohingya refugee community and 353 were from the Bangladeshi host community. All households were located in either Teknaf 297) or Ukhia 422) in Cox's Bazar, Bangladesh. We opted for these two upazilas to get variation in the longevity of the camps, as Teknaf hosts camps that were established in the 1990s. Households were drawn at random, using sampling frames based on mauzas for the host community and camp block for the refugee community. This is the same sampling procedure as the one used by Lopez-Pena et al. (2020). The survey was administered between July 18, 2020 and August 2, 2020. We only sampled households with school age children. Thus, of the 719 households, 103 did not have any school aged children and are therefore excluded from the statistics presented here. We interviewed both male and female heads of households.

\subsection{Ethical Considerations}

We followed the same protocol and consent script used in established survey projects on the Rohingya refugee population. Moreover, one of the authors speaks Bengali and worked with the local enumerators to make sure that the consent script and the questions were culturally appropriate for both the host community and the refugees. Prior to the pandemic started in Banlgadesh in March 2020, we visited the areas in order to vet the questions. Our consent script included a description of the research and allowed the respondent to refuse to participate at any point in time during the phone interview. We did not have any deviations from our original research plan nor any contradictions in our ethical considerations. The project did not engage in deception.

We are aware of the enormous power differential between the researchers and the refugee population. For that reason, we engaged in in-depth fieldwork (in country) prior to the implementation of the survey to ensure that the questions, the subject matter, and the approaches were appropriate in the context. We found out that respondents are eager to speak about their condition and want to speak to outsiders (because so few are allowed in). They knew that they would not receive compensation and indeed are not allowed to take cash (in the camps). During the site visits, the conversation with refugees guided a lot of the decisions made about the survey questions.

\subsection{Variables}

Recall that our goal is to understand the sources of educational services before and after the shutdown for both Rohingya refugees and the local host population. As such, we asked the respondents which educational services they were using before the lockdown in March, and which services they were using in July, during which the lockdown was active. The refugees could choose between four types of educational services, and specify others if they existed. These four types were "NGO-based learning center," "Madrasa/religious school," "Community-based/private tutoring outside of your home," and "Private tutoring in your home". The host community did not have the NGO-based option, since such services are not available to them. However, they had the additional options "Government school" and "Private school", which are not available to the refugees.

Our main dependent variable is whether or not the household used at least one educational service during the lockdown. We have two main independent variables. First, we use the number of services used by the household before the lockdown. Second, we use a dummy for each educational service, with one indicating that the household used this service before the lockdown. Thus, the first variable estimates a general effect of diversification, while the second variable estimates whether there are specific types of services that are especially associated with continued education during lockdown.

Two caveats are in order. First, we cannot conclude anything about the quality of the educational services received based on these data. Second, neither do we know how often the different educational services were used by various individuals in the 


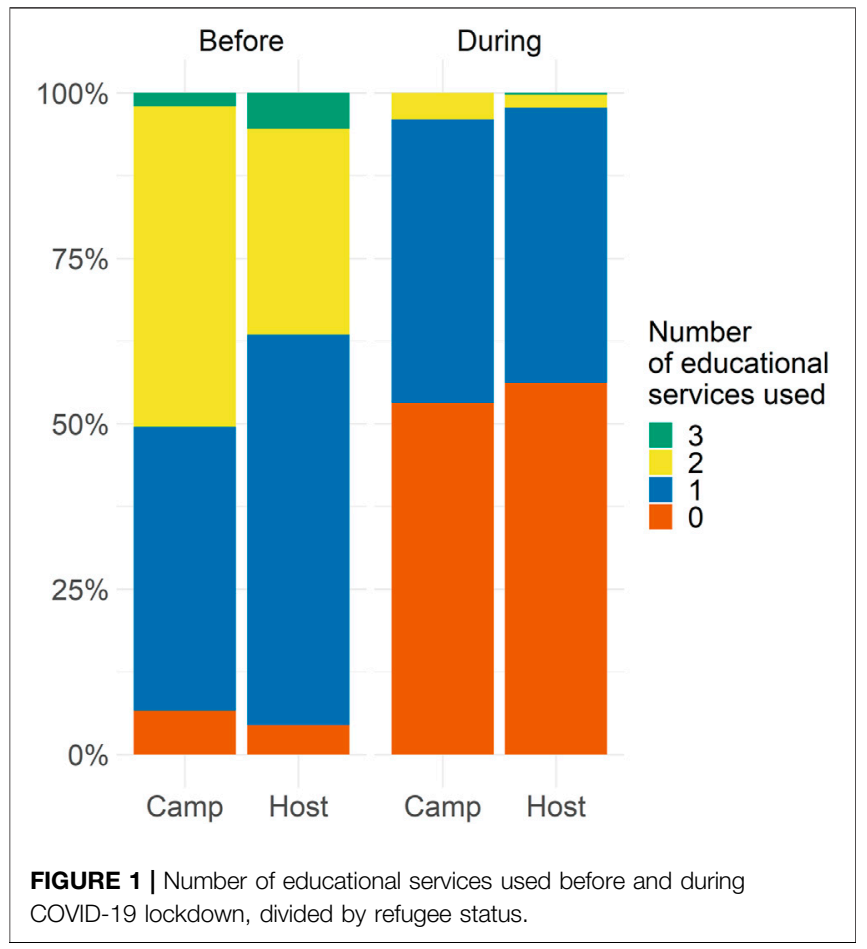

households. We therefore caution against strong conclusions on these two points. Future studies should probe more into the quality of various educational services during the lockdown.

We control for several confounders. First, we control for whether the household member are refugees or not, with the value one indicating a Bangladashi household. Second, we control for how much the household prioritizes education. In the survey, we asked the respondents to allocate 1,000 Takka across five different expenses: Fuel, religious offerings/activities, medications, savings, and education. ${ }^{5}$ In addition, the respondent could allocate to an 'other' category. The variable is divided by 10 to arrive at the percent allocated to education. We use the amount allocated to education as a measure of how much education is prioritized in the household. While this is not a perfect measure of prioritization, we believe it sufficiently captures the phenomenon, while hopefully minimizing the social-desirability bias in asking about the value of education directly. Third, we control for the household income. The measure is reported in Takka, and we use the natural logarithm. We add one to the original value to deal with transformation of 0 . Last, we control for the number of children, since more children should make it more likely that a household uses an educational service for at least one of them.

An overview of all descriptive statistics is available in Supplementary Appendix Table A1. The survey items are printed in Supplementary Appendix Tables D3,D4.
TABLE 1 | Association between prior education services and continued education during lockdown.

\begin{tabular}{|c|c|c|}
\hline Covariate & Model 1 & Model 2 \\
\hline N services before & $0.108^{\star \star}(0.033)$ & \\
\hline Used other service & & $0.325^{\star}(0.147)$ \\
\hline Used community school & & $0.315^{\star}(0.141)$ \\
\hline Used home tutor & & $0.307^{\star}(0.126)$ \\
\hline Used NGO & & $0.151^{*}(0.07)$ \\
\hline Used religious school & & $0.091^{*}(0.044)$ \\
\hline Used government school & & $0.074(0.06)$ \\
\hline Used private school & & 0.059 (0.058) \\
\hline Host (vs refugee) & 0.107 (0.114) & $0.154(0.126)$ \\
\hline Pct. Takka to education & $0.003^{\star \star \star}(0.001)$ & $0.003^{\star \star \star}(0.001)$ \\
\hline Ln income & $-0.015(0.008)$ & $-0.013(0.008)$ \\
\hline $\mathrm{N}$ children & $0.025(0.017)$ & $0.026(0.017)$ \\
\hline Constant & $0.234^{*}(0.092)$ & $0.192(0.101)$ \\
\hline Camp/Mauza FE & Yes & Yes \\
\hline $\mathrm{N}$ & 615 & 615 \\
\hline Model type & Im & Im \\
\hline Adj. R-squared & 0.125 & 0.128 \\
\hline
\end{tabular}

\section{RESULTS}

\subsection{Descriptive Statistics}

Our first task is to show the educational differences between refugee and host communities prior to the shut down. We posited that access to education would be more diverse for the Rohingya refugees in comparison to the host population, in order to compensate for deficits in each individual service. Figure 1 shows that the Rohingya households were more likely to not use any educational service, but also more likely to rely on more than one educational service provider: More than half of the Rohingya household use two or more providers. The most common combination, used by half of all Rohingya households, is to combine NGO provided services with religious education. The host community on the other hand, to a large extent relied on one provider, and the most common providers were either religious (but still government) (48\%), private (44\%), or public schools (39\%).

Second, we posited that because refugees would have a more diversified set of informal ties to education, they would use these informal networks during the shut down. In contrast, the host population's access to education services would decline because they had fewer prior informal options. Our data show that during the shut down, half of all households, both among the host community and refugee community, did not have access to any educational services.

\subsection{Regression Analyses}

Next, we turn our attention to more systematic regression analyses. Here we are interested in whether households that used a more diversified set of educational services were more likely to continue some form of education during the lockdown. Two models are reported in Table 1, using the two different treatment variables explained above.

In Model 1, we see that more educational services is clearly associated with continued education during lockdown. The use of

\footnotetext{
${ }^{5} 1,000$ Takka is approximately 12 USD
} 
one additional service is associated with 10 percentage points increase in probability to continue education during lockdown. It might be that this effect is not linear. In the Supplementary Appendix Table B2 we show that there is indeed a positive association for each increase in the number of services (between 0 and 3).

In Model 2, we see clear variation in the association between the different educational providers before lockdown, and continued education during. Notably, the most informal forms of education-community-driven schools, the various "other services", and private home tutors-are most strongly associated with continued education. Using any of these services is associated with a 30 percentage points increase in the likelihood of continued education during lockdown. Furthermore, both NGO-provided services and religious school have a positive association with continued education, 15 and 9 percentage points respectively. Thus, the results strongly confirm our hypothesis that families who have experience with maneuvering the informal sector are more likely to find alternatives during crises.

The only type of services without any significant association with continued education, are public and private schools. These are arguably the most financially stable services, and with the highest quality. We contend that the households that use such services are less likely to compensate for a educational deficit, and were therefore more vulnerable when the schools system closed. Those who used them had no immediate, other alternatives. In the supporting information we also present a mediation analysis which gives suggestive evidence to our hypothesis (Imai et al., 2011).

\section{CONCLUSION}

The COVID-19 pandemic shut down not only governments' abilities to provide services, but also international organizations' service provisions to the most vulnerable populations-refugees. To make up for the potentially less reliable and more inconsistent provision of services by IOs, refugees turn to more informal service providers than host communities. Our data show that refugees use a higher number of service providers for education than host communities. Counter intuitively, refugee access to informal suppliers of education enabled them to turn to those informal options during the pandemic. Refugees had a wider set of education options-they relied on private tutors, religious educational services as well as community based education services. The host community only turned to private tutors during the lockdown.

Our findings point to two important implications. First, even though refugees had more alternatives than the host community for education services and possibly other services, the quality of those services is likely to be poor. Informal education, or ad hoc service provision, lack sustained funding and resources, and lack

\section{REFERENCES}

Alix-Garcia, J., Walker, S., Batlet, A., and Order, H., (2018). Do refugee Camps Help or Hurt Hosts? the Case of Kakuma, Kenya. J. Development Econ. 130, 66-83. doi:10.1016/j.jdeveco.2017.09.005 standardization and oversight. Thus, in the long-term even though some refugees had access to education, the value of the education that children receive during the pandemic remains dubious. Second, the service gaps by governments and IOs enable other actors such as religious leaders, community leaders, and others to fill the void. Informal actors are able to gain more of a foothold through service provision when formal governance structures shut down. This could mean heightened competition in governance and potential weakness in formal institutions if the informal actors continue to compete with formal governance structures when the pandemic ends. A long-term consequence of the shut-down may be lower quality governance and potentially less compliance with formal institutions such as the IOs and the government.

The COVID-19 pandemic forced IOs and governments to difficult choices. Efforts to stop the spread of the disease today, risk creating new problems tomorrow. Our study shows how refugees are resilient. However, without clear strategies for handling shutdowns in the future, IOs that are meant to protect refugees may lose their status over the camps, reducing the quality of overall governance.

\section{DATA AVAILABILITY STATEMENT}

The raw data supporting the conclusion of this article will be made available by the authors, without undue reservation.

\section{ETHICS STATEMENT}

The studies involving human participants were reviewed and approved by the Norwegian center for research data Institutional Review Board Cornell University Institutional Review Board Innovation for Poverty Action. Written informed consent for participation was not required for this study in accordance with the national legislation and the institutional requirements.

\section{AUTHOR CONTRIBUTIONS}

All authors listed have made a substantial, direct, and intellectual contribution to the work and approved it for publication.

\section{SUPPLEMENTARY MATERIAL}

The Supplementary Material for this article can be found online at: https:/www.frontiersin.org/articles/10.3389/feduc.2021.696176/ full\#supplementary-material

Arifuzzaman, M., Siam, Z. S., Rashid, M. D. H., and Islam, M. D. S., (2021). No Lockdown Policy for COVID-19 Epidemic in Bangladesh: Good, Bad or Ugly? Int. J. Mod. Phys. C 32 (5), 2150062. doi:10.1142/ S0129183121500625

Arjona, A., Kasfir, N., and Mampilly, Z. (2015). Rebel Governance in Civil War. Cambridge University Press. 
Asadullah, M. N., and Chaudhury, N. (2010). Religious Schools, Social Values, and Economic Attitudes: Evidence from Bangladesh. World Development 38 (2), 205-217. Barnett, M. N. (2013). Humanitarian Governance. Annu. Rev. Polit. Sci., 16, 379-398.

Bayram, A. B., and Graham, E. R. (2015). Financing Global Governance: Explaining Donor Funding Patterns at International Organizations. Review of International Organizations, 12, 421-459.

Campbell, S. P. (2018). Global Governance and Local Peace: Accountability and Performance in International Peacebuilding. Cambridge University Press.

Caplan, R. (2005). International Governance of War-Torn Territories: Rule and Reconstruction. Oxford University Press.

Chowdhury, S. R. (2020). "Response to COVID-19 in Bangladesh: Strategies to Resist the Growing Trend of COVID-19 in a Less Restricted Situation Tachlima Chowdhury Sunna, and Shubrandu Sanjoy. Asia Pac. J. Public Health, 1-3.

ChowdhuryMushtaque, A. R., and Choudhury, R. K., (1999). Hope Not Complacency: State of Primary Education in Bangladesh 1999. Campaign for Popular Education The University Press Limited.

ChowdhuryMushtaque, A. R., Nath, S. R., and Choudhury, R. K. (2003). Equity Gains in Bangladesh Primary Education. Int. Rev. Educ. 49 (6), 601-619.

Cohen, J., and Bloom, D. E. (2006). Universal Basic and Secondary Education. Educating All Children: A Glob. agenda. 18, 213-216.

Cox's Baar Education Sector (2018). Joint Education Needs Assessment: Rohingya Refugee In Cox's Bazar. Cox's Baar Education Sector.

Dupuy, K., Gjerløw, H., Haque, M. A., Mahmud, S., Nilsen, M., and Østby, G., (2019). Mapping Education Programmes for Rohingya Refugees in BangladeshPolicy Brief 07/2019. PRIO.

Dupuy, K., and Østby, G. (2019). No Right to Read: Regulatory Restrictionson Refugee Rights to Formal Education. PRIO Policy Brief. PRIO.

Egede, L. E., and Walker, R. J. (2020). "Structural Racism, Social Risk Factors, and Covid-19-A Dangerous Convergence for Black Americans. New Engl. J. Med. 383 (12).

Frey, B. S. (2008). "Outside and inside Competition for International Organizations- from Analysis to Innovations. The Rev. Int. Organizations, 3, 335-350.

Fund, M. (2020). Girls' Education and COVID-19: What Past Shocks Can Teach Us about Mitigating the Impact of Pandemics. Malala Fund.

Gray, J. (2018). Life, Death, or Zombie? the Vitality of International Organizations. Int. Stud. Q. 62 (1), 1-13.

Hale, T., Angrist, N., Kira, B., Petherick, A., Phillips, T., Tatlow, H., et al. (2021). A Global Panel Database of Pandemic Policies (Oxford COVID-19 Government Response Tracker). Nat. Hum. Behav., 5, 529-538. 10.1038/s41562-02101079-8

Imai, K., Keele, L., Tingley, D., and Yamamoto, T., (2011). Unpacking the Black Box of Causality: Learning about Causal Mechanisms from Experimental and Observational Studies. Am. Polit. Sci. Rev. 105 (4), 765-789. 10.1017/ S0003055411000414

Lake, M. M. (2018). Strong NGOs and Weak States: Pursuing Gender justice in the Democratic Republic of Congo and South Africa. Cambridge University Press.

Lessing, B., and Willis, G. D. (2019). Legitimacy in Criminal Governance: Managing a Drug empire from behind Bars. Am. Polit. Sci. Rev. 113 (2), 584-606.

Littoz-Monnet, A. (2017). The Politics of Expertise in International Organizations: How International Bureaucracies Produce and Mobilize Knowledge. Taylor \& Francis.
Lopez-Pena, P., Davis, C. A., Mobarak, A. M., Raihan, S., et al. (2020). Prevalence of COVID-19 Symptoms, Risk Factors, and Health Behaviors in Host and Refugee Communities in Cox's Bazar: a Representative Panel Study. Bull World Health Organ. doi:10.2471/BLT.20.265173

Mahoudeau, A. (2019). 'Who Is Responsible about Our lives?' Failing" Governance and Mobilizations in the Palestinian Refugee Camps of Beirut. J. Urban Aff., 1-15. 10.1080/07352166.2019.1676645

Miller, S. D. (2017). UNHCR as a Surrogate State: Protracted Refugee Situations. Routledge.

Mousumi, M. A., and Kusakabe, T. (2020). "School Education System in Bangladesh". In: Handbook of Education Systems in South Asia. Ed. by Padma M. Sarangapani and Rekha Pappu. Springer, pp. 1-36.

Nelson, R. W. (1986). International Law and US Withholding of Payments to International Organizations. Am. J. Int. L. 80 (4), 973-983.

Pillai, S., and Zireva, R. (2020). Covid 19 Response Strategy, 2020: Reach Every Learner. Cox's Bazar Education Sector. Cox's Bazar: Education Sector Coordinators.

Risse, T., and Stollenwerk, E. (2018). Legitimacy in Areas of Limited Statehood. Annu. Rev. Polit. Sci., 21, 403-418.

Schmelzle, C., and Stollenwerk, E. (2018). Virtuous or Vicious circle? Governance Effectiveness and Legitimacy in Areas of Limited Statehood.

Schneiker, A. (2018). Transnational Expertise: Internal Cohesion and External Recognition of Expert Groups, Vol. 3. Nomos Verlag.

Siam, Z. S., Arifuzzaman, M. D., Ahmed, M. D. S., Ahamedkhan, F., Rashid, M. D. H., and Islam, M. D. S. (2021). Dynamics of COVID-19 Transmission in Dhaka and Chittagong: Two Business Hubs of Bangladesh. Clin. Epidemology Glob. Health, 10, 100684. doi:10.1016/j.cegh.2020.100684

Skarbek, D. (2011). Governance and Prison Gangs. Am. Polit. Sci. Rev. 105 (4), $702-716$.

Spoerri, M., Ullah, Y., and Chloé Nwangwu, N. (2020). The Rohingya and COVID19: Towards an Inclusive and Sustainable Policy Response. Independent Diplomat.

Ullah, A. K. M. A., Hossain, M. A., and Chattoraj, D. (2020). Covid-19 and Rohingya Refugee Camps in Bangladesh. Intellect. Discourse, 228, 793-806.

Ullah, A. K. M. A. U., Nawaz, F., and Chattoraj, D. (2021). Locked up under Lockdown: The COVID-19 Pandemic and the Migrant Population. Social Sci. Humanities Open, 3.

Whitaker, B. E. (2008). Funding the International Refugee Regime: Implications for protection. Glob. Governance: A Rev. Multilateralism Int. Organizations, 14, 241-258.

Yassin, N., Nora, S., and Rassi, R. (2016). “Organized Chaos: Informal Institution Building Among Palestinian Refugees in the Maashouk Gathering in South Lebanon". In: J. Refugee Stud. 29 (3), pp. 341-362.

Conflict of Interest: The authors declare that the research was conducted in the absence of any commercial or financial relationships that could be construed as a potential conflict of interest.

Copyright (c) 2021 Gjerløw, Karim and Østby. This is an open-access article distributed under the terms of the Creative Commons Attribution License (CC $B Y$ ). The use, distribution or reproduction in other forums is permitted, provided the original author(s) and the copyright owner(s) are credited and that the original publication in this journal is cited, in accordance with accepted academic practice. No use, distribution or reproduction is permitted which does not comply with these terms. 